\title{
DNA barcoding approaches for fishing authentication of exploited grouper species including the endangered and legally protected goliath grouper Epinephelus itajara
}

\author{
RODRIGO A. TORRES ${ }^{1}$, RAFAEL B. FEITOSA ${ }^{1}$, DANIEL C. CARVALHO ${ }^{2}$, \\ MATHEUS O. FREITAS ${ }^{3}$, MAURICIO HOSTIM-SILVA ${ }^{4}$ and BEATRICE P. FERREIRA ${ }^{5}$ \\ ${ }^{1}$ Laboratório de Genômica Evolutiva e Ambiental, Departamento de Zoologia, Universidade Federal de Pernambuco, \\ Av. Prof. Nelson Chaves, s/n, Cidade Universitária, Recife, PE, Brazil, CEP 50760-420. E-mail: rodrigotorres@ ufpe.br \\ ${ }_{2}^{2}$ Pontifícia Universidade Católica de Minas Gerais, Belo Horizonte, MG, Brazil. \\ ${ }^{3}$ Programa Pós Graduação em Ecologia e Conservação - Universidade Federal do Paraná, Setor de Ciências Biológicas, \\ Caixa Postal 19031, CEP 81531-980, Curitiba, PR, Brazil. \\ ${ }^{4}$ Universidade Federal do Espírito Santo, CEUNES, DCAB, Campus de São Mateus, São Mateus, ES, Brazil. \\ ${ }_{5}^{5}$ Departamento de Oceanografia, Universidade Federal de Pernambuco, Recife, PE, Brazil.
}

SUMMARY: Fishing strategies are constantly changing to meet the needs for new or alternative food sources. Consequently, management of fishing activities regarding rates of exploitation is essential, as a number of resources have reached situations of overexploitation. The aim of the present study was to use DNA barcoding from the goliath grouper and other exploited epinephelids in order to provide procedures for DNA authentication to be used as evidence for combating putative illegal fishing. The species studied were Epinephelus adscensionis, Mycteroperca bonaci, Mycteroperca interstitialis, Epinephelus itajara, Mycteroperca venenosa, Epinephelus mystacinus, Dermatolepis inermis, Alphestes afer, Cephalopholis fulva, Mycteroperca acutirostris, Rypticus saponaceus, Mycteroperca marginata and Epinephelus morio. Four of these species are the main epinephelids fished in the Atlantic Ocean. Differential patterns of polymerase chain reaction-restriction fragment length polymorphism were obtained from the species and additional single nucleotide polymorphisms were also detected among the four main epinephelids studied. The procedures proved very efficient and we suggest their applicability to the other fish groups as a way to control illegal capture and retail around the world, especially in cases in which filleting and other forms of de-characterization cause a lack of morpho-anatomical key characters.

Keywords: DNA authentication, PCR-RFLPs, SNPs, groupers, goliath grouper, epinephelids.

RESUMEN: AUTENTICACIÓN MEDIANTE DNA BARCODING DE ESPECIES DE MEROS LEGALMENTE PROTEGIDAS Y EN PELIGRO DE EXTINCIÓN, SOMETIDAS A EXPLOTACIÓN PESQUERA, INCLUYENDO EL MERO GOLIAT EPINEPHELUS ITAJARA. - Las estrategias de pesca cambian constantemente para satisfacer las necesidades de fuentes de alimento nuevas o alternativas. En consecuencia, a medida que los recursos alcanzan situaciones de sobreexplotación, resulta esencial establecer procedimientos de inspección de las actividades relacionadas con las tasas de explotación pesquera. El objetivo de este estudio es proponer el uso de la técnica de DNA barcoding para establecer la verificación de la identidad del mero Goliat y otros epinefélidos, a fin de utilizarlo como evidencia para combatir la pesca ilegal cuando se sospeche su ocurrencia. Las especies aquí estudiadas fueron Alphestes afer, Cephalopholis fulva, Dermatolepis inermis, Epinephelus adscensionis, E. itajara, E. morio, E. mystacinus, Mycteroperca acutirostris, M. bonaci, M. interstitialis, M. marginata, M. venenosa y Rypticus saponaceus de las cuales cuatro constituyen las más pescadas en el Océano Atlántico. Fueron encontrados patrones diferenciables de PCR-RFLPs para todas las especies y, además, fue posible detectar SNPs adicionales entre las cuatro especies más explotadas. Los procedimientos aquí empleados fueron muy eficaces por lo que sugerimos su aplicabilidad a otros grupos de peces como medida de control de la captura y comercialización ilegal a nivel mundial, particularmente en aquellos casos en los que el fileteado y otras formas de procesamiento que alteran las características anatómicas y morfológicas impiden su identificación.

Palabras clave: verificación mediante ADN, meros, mero Goliat, PCR-RFLPs, SNPs, epinefélidos. 


\section{INTRODUCTION}

Molecular DNA markers are now sufficiently sophisticated to recognize genetic variants of a species. The low cost of the techniques has resulted in a recent increase in the number of studies using this approach. For example, one of the simplest, lowest-cost methods uses polymerase chain reaction-restriction fragment length polymorphisms (PCR-RFLPs) (Schlötterer 2004).

PCR-RFLP markers are commonly used and highly repeatable (Meyer et al. 1995) for the identification of a variety of species in several phyla (Wolf et al. 1999, McDonald et al. 2005, Torres 2006, Santaclara et al. 2007, Spergser and Rosengarten 2007, FernandezTajes and Méndez 2007, Sowmya et al. 2007, Kang et al. 2008). Although DNA sequencing and analysis is accurate and authentic, it is costly, time-consuming and not suitable for routine species identification studies. PCR-RFLP has been proven to be a practical, simple and rapid technique (Meyer et al. 1995, Partis et al. 2000) and a high level of expertise in molecular genetics is not necessary for interpreting results obtained in agarose gels. The technique allows mislabeled or fraudulent fish products to be detected easily (Hsieh et al. 2010). Additionally, this technique has recently been used as a forensic tool for solving crimes ("forensic genetics", Butler 2005, Jobling and Gill 2004). For example, it has been used to determine the origin of cattle meat (Verkaar et al. 2002) and illegal wildlife trading (Dubey et al. 2010).

Because of the abundance of mutations in the genomes of many species (Morin et al. 2004), single nucleotide polymorphisms (SNPs) are very effective markers for resolving similar issues. Using SNPs has become one of the most recent innovations for ecological and conservation management, especially that of the fishery industry (Morin et al. 2004, Hauser and Seeb 2008). Technological advances in fisheries have resulted in an industrial level of fishing with a much greater and widespread impact. As a consequence, regulation is required to control the exploitation of fish and prevent depletion of stocks (Pauly et al. 2002). Following the worldwide trend for marine fisheries (Pauly et al. 2005, Pauly 2009), most grouper fisheries are sharply declining, collapsing or already depleted (Morris et al. 2000, Frédou and Ferreira 2005, Mitcheson et al. 2012).

As a management tool, accurate identification of these species based on molecular authentication (e.g. DNA barcoding) is very important because species may be identified from tissue samples in the absence of morphological characters (Frézal and Leblois 2008). In addition, several molecular techniques have been used to distinguish between legal and illegal products, to relocate animals for their natural populations, and to mark and track DNA profiles (Alacs et al. 2012). Often, fish fillets are mislabeled as different species for marketing purposes or to disguise illegal capture and retail (Jacquet and Pauly 2008, Miller and Mariani 2010, Carvalho et al. 2011a, b). DNA authentication through DNA barcoding has applications in ecology, medicine, epidemiology, evolutionary biology, biogeography and conservation biology (Frézal and Leblois 2008, Alacs et al. 2012), such as the use of cytochrome $\mathrm{C}$ oxidase for species delimitation and fishing authentication (Hebert et al. 2003, 2004a, Sass et al. 2007, Hajibabaei et al. 2007, Linacre and Tobe 2011, Carvalho et al. 2011b).

The grouper family (Epinephelidae) comprises 62 genera and 449 species (Heemstra and Randall 1993, Nelson 2006), many of which are exploited throughout the world (Morris et al. 2000, Mitcheson, et al. 2008, Mitcheson et al. 2012) and comprise some of the most important fishery resources in the tropical west Atlantic (Heemstra and Randall 1993, Claro et al. 2001). Due to over-fishing, the goliath grouper (Epinephelus itajara) is critically endangered and consequently its capture is prohibited in several countries, including Brazil (IBAMA 2007, IUCN 2008). Also, because of its slow development in brackish waters, it requires many years to recover (Sadovy and Eklund 1999, Frias-Torres 2007). Traditional knowledge about the ecology and habits of the grouper among local, small-scale fishermen, has been very important for the conservation of the goliath grouper in Brazil (Hostim-Silva et al. 2005, Gerhardinger et al. 2009). Other species of grouper, including the dusky (formerly Mycteroperca marginata sensu Craig and Hastings 2007), red (Epinephelus morio) and black (M. bonaci), are also exploited, yet their conservation receives less attention worldwide (Gimenez-Hurtado et al. 2005, Machado et al. 2003, Teixeira et al. 2004, Gerhardinger et al. 2006, Freitas et al. 2011). Therefore, they may suffer even greater extinction risks.

Taxonomic identification of fish is a difficult task because the way in which the fish are processed leads to a lack of diagnostic morphological characters. This favours the illegal trade of prohibited species because the fish can be sold under the name of similar, legally caught fish (Wong and Hanner 2008). In the case of E. itajara in Brazil, knowledge about the fish ban is widespread, so illegal traders also use filleting to trade it mislabeled as other species of grouper. In these cases, environmental law enforcement is often hampered by absence of proof. Thus, DNA-based procedures are valuable tools for law enforcement since they can attest the species in which is marketed. We adopted PCR-RFLP because it is less time-consuming and more cost-effective than DNA sequencing. Such methodology also requires equipment readily available in most molecular laboratories, and it has proven its utility in species identification (Palo and Merila 2003, Rohilla and Tiwari 2008, Dubey et al. 2010). Here, we examined the variability of the barcode region (COI mtDNA gene) in groupers to develop DNA authentication tools (PCR-RFLPs and SNPs), specifically the genetic signatures of the 13 commercially important 

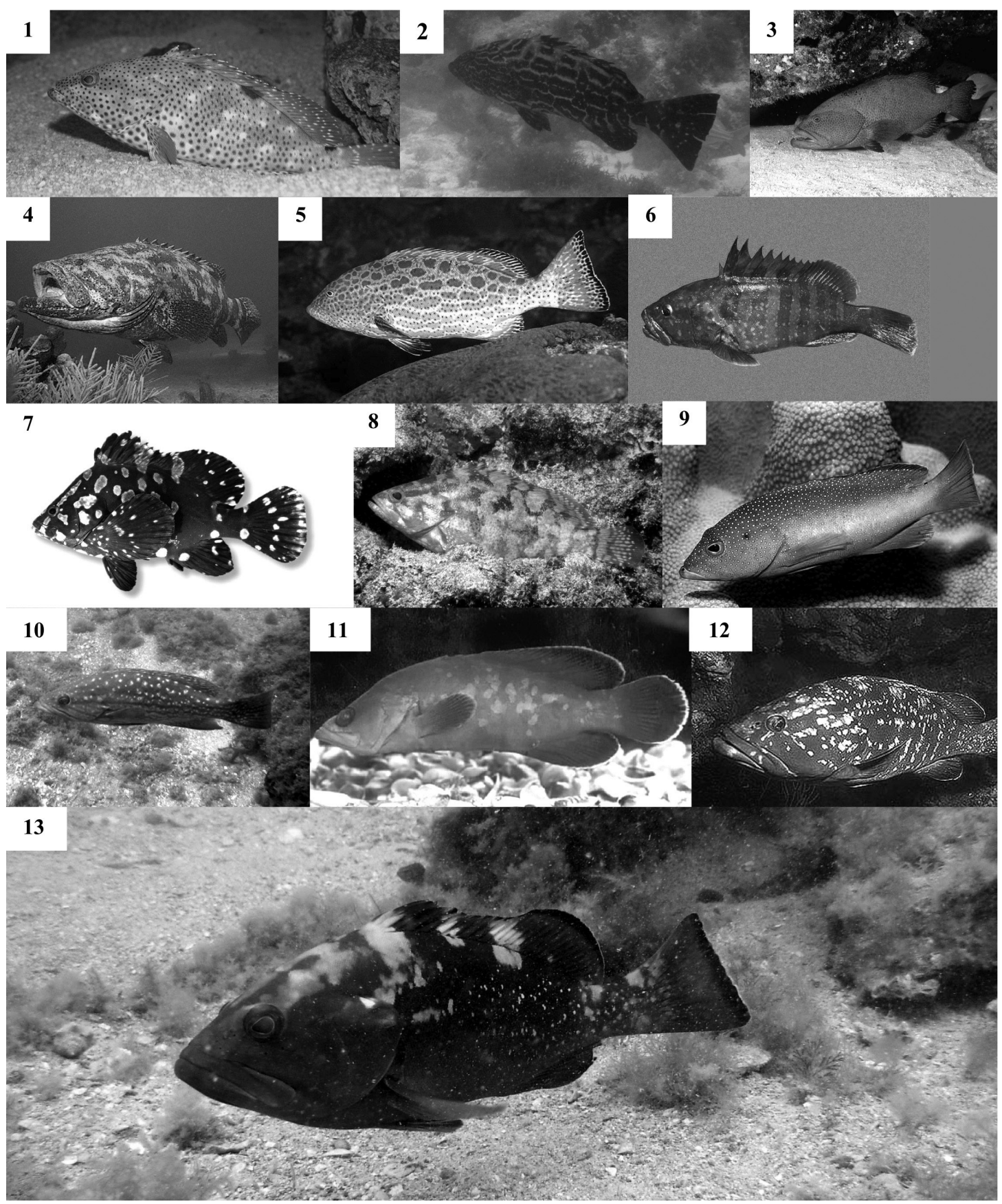

FIG. 1. - The 13 species of grouper in this study: Epinephelus adscensionis (1), Mycteroperca bonaci (2), Mycteroperca interstitialis (3), Epinephelus itajara (4), Mycteroperca venenosa (5), Epinephelus mystacinus (6), Dermatolepis inermis (7), Alphestes afer (8), Cephalopholis fulva (9), Mycteroperca acutirostris (10), Rypticus saponaceus (11), Mycteroperca marginata (12) and Epinephelus morio (13); Numbers 1-13 indicate species-specific PCR-RFLP profiles in Table 2.

species, especially the goliath (Epinephelus itajara), red (E. morio), dusky (Mycteroperca marginata) and black (M. bonaci) groupers.

\section{MATERIALS AND METHODS}

Thirteen valid species of southern Atlantic grouper were collected (Epinephelus adscensionis, E. itajara, E. mystacinus, E. morio, Mycteroperca bonaci, M. interstitialis, M. venenosa, M. acutirostris, M. marginata, Dermatolepis inermis, Alphestes afer, Cephalopholis fulva, Rypticus saponaceus) (Fig. 1). All the specimens were identified by keys following Heemstra and Randall (1993). The specimens were purchased from artisanal fishermen and, because of the taxonomic validity and rarity of the species, one specimen from each species was analysed. While intra-species variation is substantially less than inter-species variation, allowing 
accurate identification among species levels (Ward et al. 2008), COI variations were not considered. In addition, negligible nucleotide variation is expected in the barcode region between several geographically different marine fish populations $\left(\mathrm{F}_{\mathrm{ST}}<0.01 / \mathrm{p}>0.24\right.$; Ward $e t$ al. 2008).

We collected fin, liver and muscle samples that were stored in $96 \%$ ethanol (Merck) at $-20^{\circ} \mathrm{C}$. DNA extraction through the DNEasy Blood and Tissue kit (QIAGEN) followed the instructions of the manufacturer. Templates were dissolved in Tris+EDTA $(\mathrm{pH}$ 8.0) and diluted at 1:20 for PCR.

\section{PCR-RFLPs}

PCR was carried out in a final volume of $25 \mu \mathrm{L}$ containing $2.5 \mu \mathrm{L}$ of $10 \times$ PCR buffer, $1.25 \mu \mathrm{L}$ of $\mathrm{MgCl}_{2}$ (50 mM), 0.5 $\mu \mathrm{L}$ of dNTP mix $(10 \mathrm{mM}), 0.2 \mu \mathrm{L}$ of Taq polymerase $(1 \mathrm{U}), 0.26 \mu \mathrm{L}$ of each primer (forward FishF1 5' TCAACCAACCACAAAGACATTGGCAC 3' and reverse FishR1 5' TAGACTTCTGGGTGGCCAAAGAATCA 3'), $2.0 \mu \mathrm{L}$ of DNA template and $18.0 \mu \mathrm{L}$ of ultrapure water. For Mycteroperca bonaci, $M$. interstitialis and Epinephelus itajara, FishR2 (5'ACTTCAGGGTGACCGAAGAATCAGAA 3') was used as the reverse primer (Ward 2005). Reactions had an initial step of $2 \mathrm{~min}$ at $95^{\circ} \mathrm{C}$, followed by 35 cycles of $30 \mathrm{sec}$ at $94^{\circ} \mathrm{C}, 30 \mathrm{sec}$ at $54^{\circ} \mathrm{C}$ and $1 \mathrm{~min}$ at $72^{\circ} \mathrm{C}$, with a final extension step of $10 \mathrm{~min}$ at $72^{\circ} \mathrm{C}$.

COI RFLP profiles were obtained through reaction with a final volume of $20 \mu \mathrm{L}$ containing $5-10 \mu \mathrm{L}$ of the PCR products, $20 \mu \mathrm{L}$ of the $10 \times$ buffer from each enzyme (as indicated by the manufacturer), 10 units of each enzyme and ultrapure water to reach the final volume (Table 1 ). When necessary, $0.2 \mu \mathrm{L}$ of $100 \times$ bovine serum albumin was used.

RFLP reactions occurred in $90 \mathrm{~min}$ at the temperatures recommended by the manufacturer of each enzyme. Resultant products were resolved by electrophoresis in $1.5 \%$ agarose gel immersed in TBE buffer, stained with GelGreen ${ }^{\mathrm{TM}}$ (Biotium), and then photographed. The molecular weight of the fragments was estimated using a 100-bp molecular marker ladder (New England Biolabs). Few different reagent brands were tested and no different RFLP profiles were detected.

\section{Sequencing and SNP detection}

PCR fragments of $\sim 700 \mathrm{bp}$ of COI from Mycteroperca bonaci, M. marginata, Epinephelus morio and E. itajara were amplified using the primers FishF1 and FishR1 (Ward et al. 2005). The 25- $\mu \mathrm{L}$ PCR mixes comprised $19.5 \mu \mathrm{L}$ of ultrapure water, $2.5 \mu \mathrm{L}$ of PHT IB, 10X PCR buffer $\left(2.5 \mathrm{mM} \mathrm{MgCl}_{2}\right), 0.35 \mu \mathrm{L}$ of each primer $(10 \mathrm{mM}), 2.5 \mu \mathrm{L}$ of dNTP $(1 \mathrm{mM}), 0.25 \mu \mathrm{L}$ of PHT Taq polymerase $(5 \mathrm{U} / \mu \mathrm{l})$ and $1.0 \mu \mathrm{L}$ of DNA template (50-100 ng/ $\mu \mathrm{L})$. Purified PCR products (1-2 $\mu \mathrm{l})$ were sequenced bi-directionally using the BigDye
TABLE 1. - The list of the enzymes used in this study, their restriction sites $(*)$, and their temperatures of use.

\begin{tabular}{lcc}
\hline Enzymes & Restriction sites & Temperature $\left({ }^{\circ} \mathrm{C}\right) /$ time \\
\hline Alu I & AG* CT & $37 / 1$ hour \\
Bam HI & G* GATCC & $37 / 1$ hour \\
Bts CI & GGATGNN $*$ & $50 / 1$ hour \\
Eco RI & G $*$ AATTC & $37 / 1$ hour \\
Hae II & GG $*$ CC & $37 / 1$ hour \\
Hha I & GC $*$ GC & $37 / 1$ hour \\
Mbo I & GATC $*$ & $37 / 1$ hour \\
Taq I $^{\alpha}$ & T $*$ CGA & $65 / 1$ hour \\
\hline
\end{tabular}

Terminator v.3.1 Cycle Sequencing Kit (www.appliedbiosystems.com), following the manufacturer's instructions. Reactions were analysed in an automated DNA sequencer (ABI 310, Applied Biosystems). The obtained sequences were deposited in Genbank under ascension numbers (JF421452-455). Sequences were then aligned with BioEdit version 5.0.9 (Hall 1999) using ClustalW multiple alignment, with gap opening at 15 and gap extension costs at 0.3 (Hall 2001). Ambiguous extremities of the sequences were trimmed after alignment. Sequence differences were measured by the Kimura 2-parameter (K2P) model using Paup* v.4.0b10 through its graphic interface PaupUp (Calendini and Martin 2005). Detection of SNPs was performed visually, with special attention to the detection of multiple sites capable of differentiating taxa within genera and between genera and species.

\section{RESULTS}

\section{PCR-RFLPs}

COI for all species was successfully amplified using the primers FishF1 and FishR, yielding $700 \mathrm{bp}$ of PCR products (Fig. 2a). In Mycteroperca bonaci, $M$. interstitialis and Epinephelus itajara the reverse primer was substituted with FishR2 (5'ACTTCAGGGTGACCGAAGAATCAGAA3'; Ward et al. 2005) because it provided better results (Fig. 2b).

Apart from BamHI and EcoRI (data not shown), other enzymes yielded diagnosable RFLP profiles (Figs 3-5). A single undigested PCR fragment (undigested control lane) was observed with BamHI. Experiments with EcoRI also revealed a single band in all species that was slightly smaller than the undigested control lane. The remaining enzymes allowed different unique or shared PCR-RFLP profiles to be identified. For example, AluI resulted in ten species-linked profiles (Fig. 3, lanes 1-5, 9, 11 and 12) and two shared profiles (Fig. 3, lanes 6-7 and 8-10). Despite lower resolution, enzymes MboI and BtsCI allowed eight PCR-RFLP profiles to be identified (Fig. 4a, b). HaeIII, HhaI and Taq ${ }^{\alpha}$ I gave seven, six and five profiles, respectively (Fig. 5a, b, c).

Restriction experiments with AluI yielded two bands in E. itajara of 200 and 220 bp (Fig. 3, Table 2). The BtsCI experiment yielded two bands of $\sim 300$ and $400 \mathrm{bp}$ each. The HaeIII experiments yielded a 


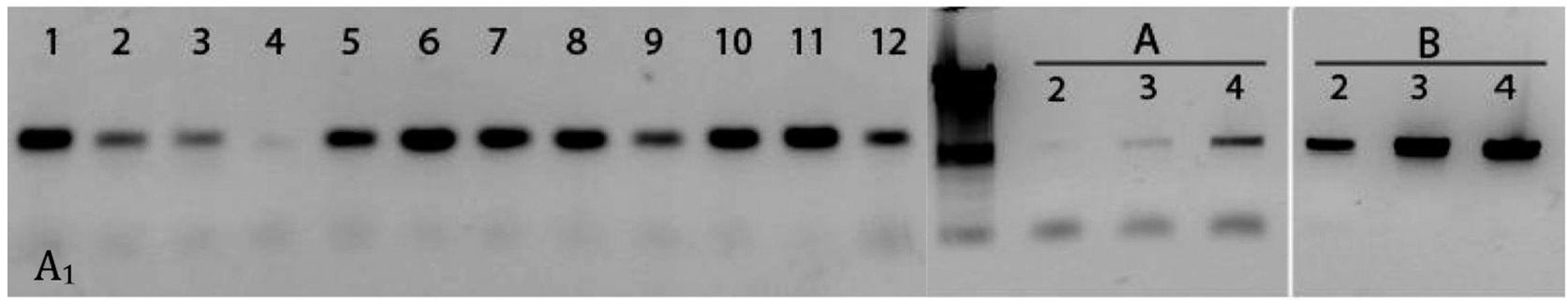

Fig. 2. - Results of amplification of the barcode regions: (A) primary PCR products ( $700 \mathrm{bp})$ from 12 grouper species using primers F1 and R1; $\left(\mathrm{A}_{1}\right)$ weak PCR products obtained with primers F1 and R2 for (2) Mycteroperca bonaci, (3) M. interstitialis and (4) Epinephelus itajara (note similar profiles in lanes 2, 3 and 4); (B) optimized PCR reactions for species using primers F1 and R2 (note three clear bands of COI for (2) Mycteroperca bonaci, (3) M. interstitialis and (4) Epinephelus itajara); numbers 1-12 indicate species as listed in Figure 1.

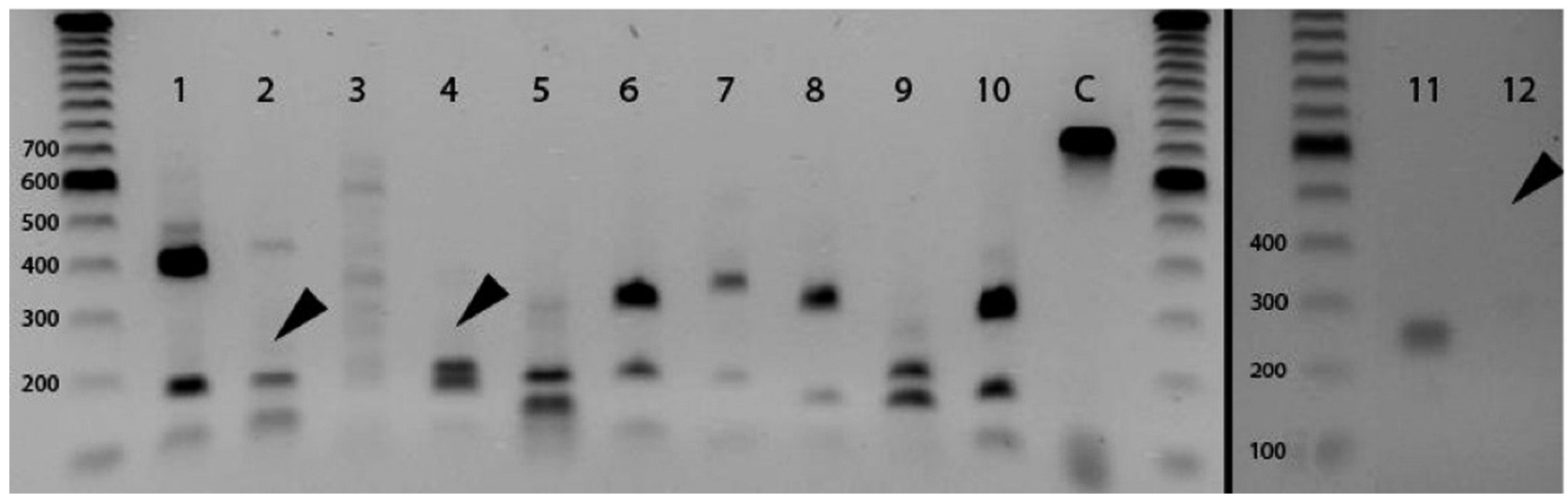

FIG. 3. - PCR-RFLPs by Alu I; Numbers 1-12 indicate species in Figure 1; "C" is undigested control lane; arrows indicate species profiles: Epinephelus itajara (4), Mycteroperca bonaci (2) and M. marginata (12) (note other unique and shared profiles).

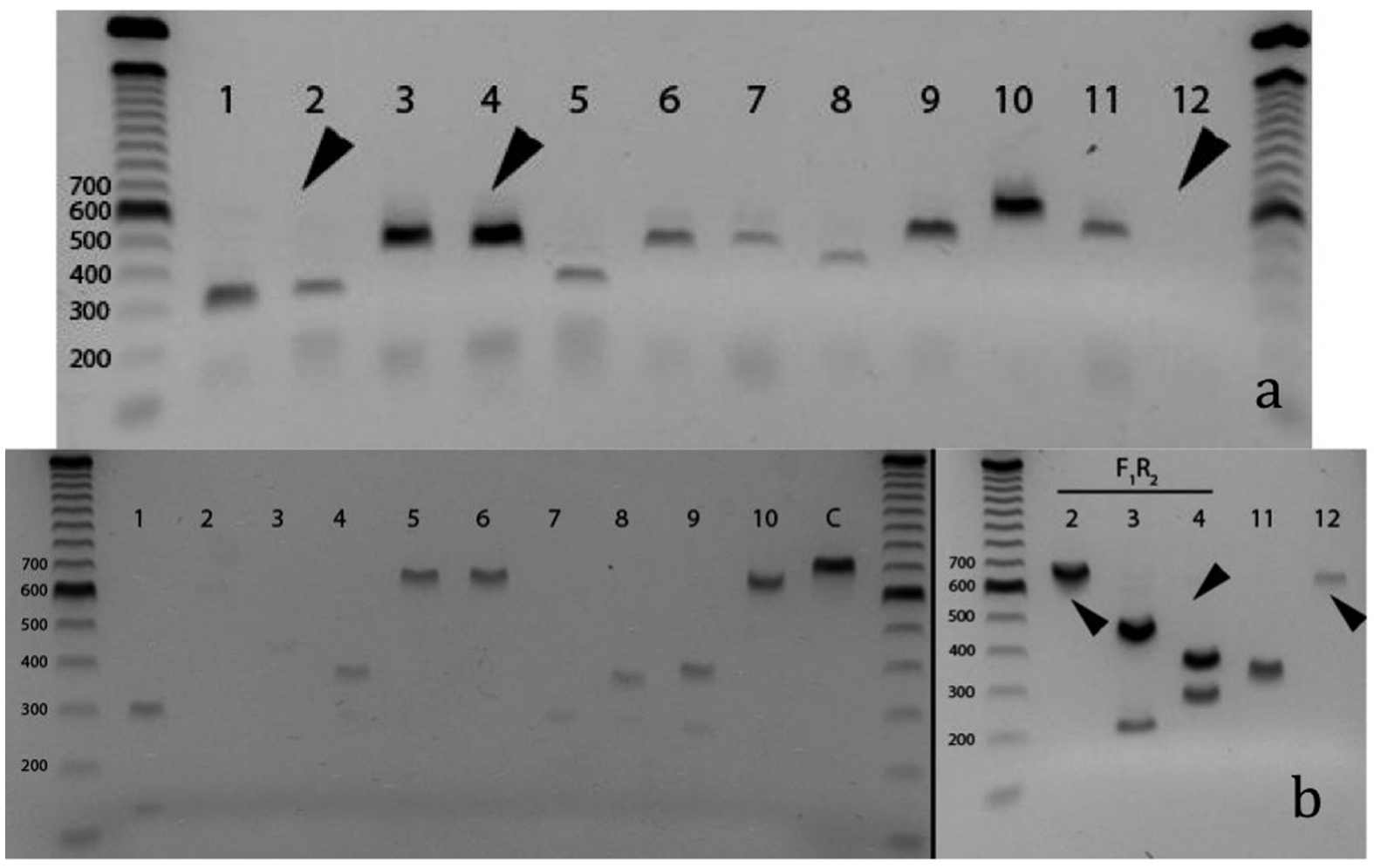

FIG. 4. - PCR-RFLPs with MboI (a) and BstCl (b); 2 and 4 indicate Mycteroperca bonaci and Epinephelus itajara respectively. Note (a), shared profile with others, except M. marginata, without bands; in (b), 2 and 4 shared RFLP profiles with other species, while Mycteroperca marginata without bands; on right, clear pattern of M. bonaci (2), M. interstitialis (3) and E. itajara (4) and shared profile of Mycteroperca marginata (12). 
$414 \cdot$ R.A. Torres et al.

TABLE 2. - PCR-RFLP profiles (in base pairs of DNA fragments) of the barcode region of the groupers in this study (species numbers as in Fig. 1).

\begin{tabular}{|c|c|c|c|c|c|c|c|c|c|c|c|c|}
\hline & \multicolumn{12}{|c|}{ Species number } \\
\hline & 1 & 2 & 3 & 4 & 5 & 6 & 7 & 8 & 9 & 10 & 11 & 12 \\
\hline$\overline{A l u \mathrm{I}}$ & $\begin{array}{l}400 \\
200\end{array}$ & 180 & $\begin{array}{l}250 \\
200 \\
150\end{array}$ & $\begin{array}{l}220 \\
200\end{array}$ & $\begin{array}{l}210 \\
180\end{array}$ & $\begin{array}{l}350 \\
220\end{array}$ & $\begin{array}{l}380 \\
220\end{array}$ & $\begin{array}{l}350 \\
200\end{array}$ & $\begin{array}{l}210 \\
180\end{array}$ & $\begin{array}{l}330 \\
200 \\
120\end{array}$ & 250 & \\
\hline Bam HI & 700 & 700 & 700 & 700 & 700 & 700 & 700 & 700 & 700 & 700 & 700 & 700 \\
\hline Bts CI & $\begin{array}{l}300 \\
150\end{array}$ & 650 & $\begin{array}{l}450 \\
250\end{array}$ & $\begin{array}{l}400 \\
300\end{array}$ & 650 & 650 & 300 & $\begin{array}{l}380 \\
300\end{array}$ & $\begin{array}{l}400 \\
270\end{array}$ & 650 & 350 & 650 \\
\hline Eco RI & 600 & 600 & 600 & 600 & 600 & 600 & 600 & 600 & 600 & 600 & 600 & 600 \\
\hline Hae III & $\begin{array}{l}400 \\
300\end{array}$ & 550 & 600 & 650 & $\begin{array}{l}350 \\
280\end{array}$ & 600 & 300 & $\begin{array}{l}350 \\
280\end{array}$ & 600 & 600 & 550 & 600 \\
\hline Hha I & 700 & 700 & 700 & $\begin{array}{l}500 \\
300\end{array}$ & 700 & 700 & 550 & 700 & 650 & $\begin{array}{l}300 \\
250\end{array}$ & 450 & $\begin{array}{l}400 \\
300\end{array}$ \\
\hline$M b o \mathrm{I}$ & 350 & $\begin{array}{l}350 \\
250\end{array}$ & $\begin{array}{l}500 \\
200\end{array}$ & $\begin{array}{l}500 \\
200\end{array}$ & $\begin{array}{l}400 \\
200\end{array}$ & $\begin{array}{l}500 \\
200\end{array}$ & $\begin{array}{l}500 \\
200\end{array}$ & $\begin{array}{l}450 \\
200\end{array}$ & 550 & 600 & 550 & \\
\hline $\operatorname{Taq}^{\alpha} \mathrm{I}$ & $\begin{array}{l}400 \\
270\end{array}$ & $\begin{array}{l}450 \\
250\end{array}$ & $\begin{array}{l}450 \\
250\end{array}$ & $\begin{array}{l}450 \\
250\end{array}$ & $\begin{array}{l}450 \\
250\end{array}$ & $\begin{array}{l}450 \\
200\end{array}$ & 600 & 600 & $\begin{array}{l}450 \\
250\end{array}$ & $\begin{array}{l}450 \\
200\end{array}$ & 600 & 400 \\
\hline
\end{tabular}

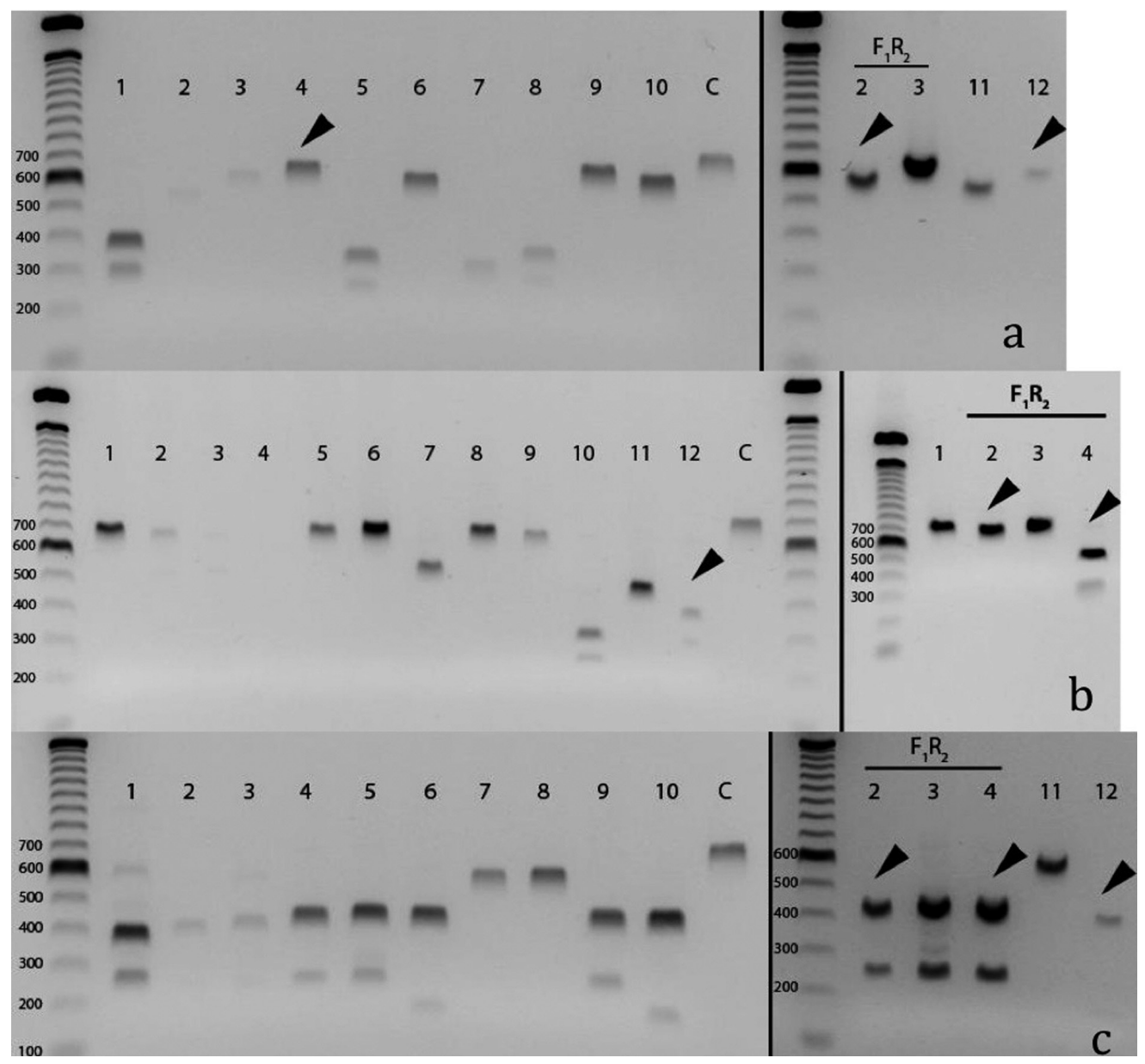

FIG. 5. - PCR-RFLPs with HaeIII (a), HhaI (b), and Taq I (c). Numbers are species in Figure 1; "C" is COI fragment without enzyme digestion; arrows indicate Mycteroperca bonaci (2), Epinephelus itajara (4) and Mycteroperca marginata (12); on right, optimized PCR reactions for species with F1 and R2. Note in (a) slightly different COI genetic profiles; in (b) clearly different COI genetic profiles and in (c) genetically unique Mycteroperca marginata. 


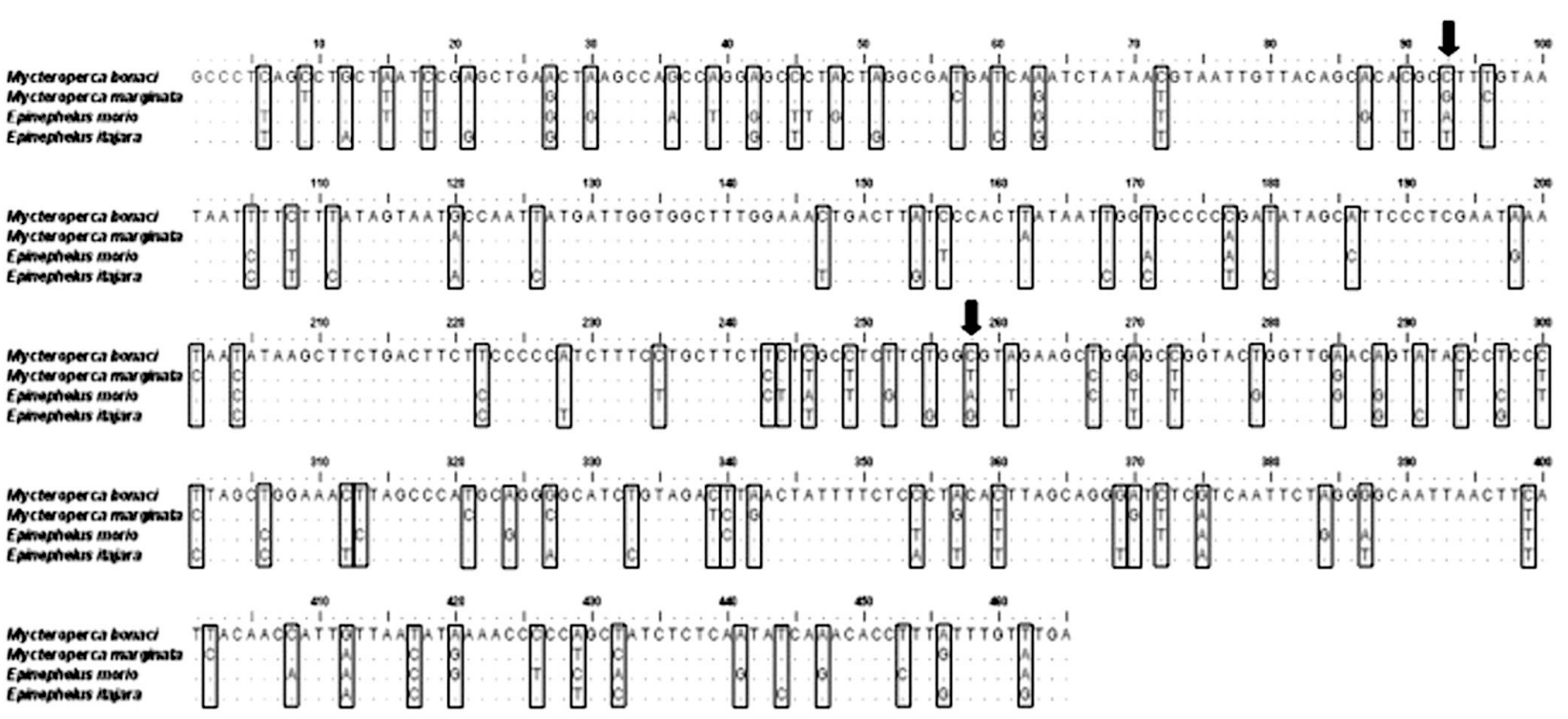

FIG. 6. - Aligned sequences from Mycteroperca bonaci, M. marginata, Epinephelus morio and E. itajara. Boxes indicate the SNP positions among the analyzed species; arrows indicate two SNP positions that uniquely identify all species.

TABLE 3. - Observed K2P COI differences (\%) among the four groupers analysed.

\begin{tabular}{lcccc}
\hline & 1 & 2 & 3 & 4 \\
\hline 1 Mycteroperca bonaci & - & & & \\
2 Mycteroperca marginata & 10.3 & - & & \\
3 Epinephelus itajara & 12.6 & 13.9 & - & \\
4 Epinephelus morio & 15.5 & 13.4 & 16 & - \\
\hline
\end{tabular}

single band of $650 \mathrm{bp}$. Two bands each resulted from enzymes MboI (200 and $500 \mathrm{bp})$ and Taq ${ }^{\alpha} \mathrm{I}(250$ and 450 bp; Figs 4a, 5c; Table 2).

Genetic profiles had lower resolution in M. marginata. Enzymes AluI and MboI gave no visible bands
(Figs 3 and 4a, Table 2). The restriction experiments with BtsCI, EcoRI, HaeIII and Taq ${ }^{\alpha}$ each yielded a single band $(650,600,600$ and $400 \mathrm{bp}$, respectively; Figs 3b, 5b, 6a, c, Table 2). Experiments with HhaI revealed two distinguishable bands (400 and $300 \mathrm{bp}$; Fig. 5b, Table 2).

In $M$. bonaci, the restriction experiments with enzymes AluI, BtsCI, HaeIII, and HhaI each revealed a single band (180, 650, 550 and $700 \mathrm{bp}$, respectively; Figs 3, 4b, 5a, b, Table 2). Two bands each resulted from enzymes MboI (250 and $350 \mathrm{bp}$ ) and $\mathrm{Taq}^{\alpha} \mathrm{I}$ (250 and $450 \mathrm{pb}$; Figs 4a, 5c, Table 2).

TABLE 4. - SNP positions for species and genera identification. The numbers indicate sites in the alignment (Fig. 7).

\begin{tabular}{|c|c|c|c|}
\hline Species & Identify species & Identify genera & $\begin{array}{l}\text { Shared between both } \\
\text { genera }\end{array}$ \\
\hline Mycteroperca bonaci & $\begin{array}{c}18,72,93,204,246,258 \\
270,360,375,399,412,417 \\
429,432,462\end{array}$ & \multirow{2}{*}{$\begin{array}{c}9,15,18,57,63,72,93, \\
96,162,177,201,204, \\
243,246,249,258,267, \\
270,273,285,294,300, \\
301,321,327,339,340, \\
342,357,360,370,372, \\
375,399,402,412,420, \\
429,432,456,462 .\end{array}$} & \\
\hline Mycteroperca marginata & $\begin{array}{c}9,57,93,96,162,201,258 \\
270,321,327,339,342,357 \\
370,402\end{array}$ & & \\
\hline Epinephelus morio & $\begin{array}{c}30,36,39,46,47,87,93 \\
156,171,186,198,235,244 \\
246,252,258,261,279,297 \\
313,324,354,384,387,408 \\
429,432,441,447\end{array}$ & \multirow{2}{*}{$\begin{array}{l}12,15,21,30,36,39,46, \\
48,51,60,87,93,111, \\
120,126,147,154,156, \\
168,171,177,180,186, \\
198,228,235,244,246, \\
252,255,258,267,273, \\
279,285,291,294,297, \\
300,301,312,313,324, \\
327,333,340,354,357, \\
369,372,384,387,408, \\
420,426,429,432,441, \\
444,447,453,456,462 .\end{array}$} & \\
\hline Epinephelus itajara & $\begin{array}{l}12,21,51,60,93,126,111 \\
147,154,168,171,177,180 \\
228,255,258,291,297,312 \\
327,333,354,357,369,387 \\
444,462\end{array}$ & & \\
\hline Mycteroperca-Epinephelus & & & $\begin{array}{c}6,42,45,90,105,108, \\
222,288,306,\end{array}$ \\
\hline
\end{tabular}




\section{Sequencing and SNPs}

An edited/aligned block comprising 465 homologous sites was obtained after sequence editing and alignment (Fig. 6) in which no insertions, deletions or stop codons were observed. This last observation prevented the use of nuclear COI pseudogenes (nuclear mitochondrial sequences - NUMTs; Song et al. 2008). Among the sequences the percentage differences (K2P) ranged from 10.3 to 16 (Table 3) and 94 SNPs were useful for diagnosis of within- and betweengenera and among-species comparisons (Fig. 6; gray boxes). Of these sites, autapomorphic SNPs support clear identification for several species: 15 identify $M$. bonaci (black grouper; Table 4), 15 identify M. marginata (dusky grouper; Table 4), 29 identify E. morio (red grouper; Table 4), and 27 identify E. itajara (goliath grouper; Table 4). A total of 41 SNPs supported differentiations between Mycteroperca spp. (Table 4), 63 supported differentiations between Epinephelus spp. (Table 4), two simultaneously supported amongspecies identification (Fig. 6; black arrows), and nine supported among-genera identification (Mycteroperca $\times$ Epinephelus) (Table 4).

\section{DISCUSSION}

\section{PCR-RFLPs}

Our PCR-RFLP analyses allowed us to correctly identify 12 species of grouper, including the endangered goliath grouper, using individual or combined genetic profiles obtained with a few restriction enzymes (Table 2, Figs 3, 4a, b, 5a-c). Thus, our results provide useful DNA authentication tools for identifying fishing of goliath (Epinephelus itajara), dusky (Mycteroperca marginata), and black (Mycteroperca bonaci) groupers without morphological characters in hand, as in fish markets. Considering the extreme risk of extinction of the analysed species (Mitcheson et al. 2008, Mitcheson et al. 2012), our finding are very welcome for grouper fishery management. While laws protect endangered fish such as goliath grouper, these laws have been futile due to the lack of an effective means of identifying illegal catches. Thus, our results provide the resolution of this important problem, especially for the goliath, dusky (M. marginata) and black (M. bonaci) groupers.

With a properly amplified barcode segment for all species (Fig. 2), a small adjustment improved resolution for those three species. That is, the replacement of the reverse primer (Fig. 2) improved resolution by avoiding the formation of nonspecific PCR products (possibly from $C O I$ ). Thus, $\mathrm{F} 1$ and $\mathrm{R} 1 / \mathrm{R} 2$ primers are specific for COI amplifications, and homology was shown by identical molecular weight for these three species with F1 and R2 primers (Ward et al. 2005).

In considering the use of the eight enzymes in procedures for DNA authentication of fishing (PCRRFLPs), the enzymes BamHI and EcoRI yielded very similar RFLP profiles with a single band for each of the 12 species (data not shown). It is possible that a priori these enzymes were not used because the terminal $\mathrm{COI}$ region in all 12 species may have been cut into tiny fragments of low molecular weight. Nonetheless, these enzymes may be effectively used to prove that a putative fish sample was not a grouper when more than a single band appears.

Clear authentication of illegal fishing of these fish can be resolved through the use of five enzymes. The goliath grouper had RFLP profiles shared by two of the six enzymes (MboI and Taq I; Figs 3 and 5, respectively), yet had unique RFLP profiles for AluI, BtsCI and HhaI (Figs 3, 4b, 5b). Thus, these data show that a combination of these profiles will provide clear forensic evidence for the goliath grouper.

Similarly, the black grouper (Mycteroperca bonaci) had a RFLP profile shared with the goliath grouper in the enzyme Taq ${ }^{\alpha}$ (Fig. 5c). With enzymes AluI and MboI, identification is much better, with a single band of $\sim 180 \mathrm{bp}$ (AluI) and two bands of $\sim 250$ and $350 \mathrm{pb}$ (MboI, Figs 3 and 4a). Also, the dusky grouper ( $M$. marginata) is identified by the combined RFLP profiles of AluI (Fig. 3), HhaI (Fig. 5b), and Taq ${ }^{\alpha}$ (Fig. 5). By using the genetic signatures of each species (Table 2 ), the necessary steps of using a single or combined genetic profile are shown for DNA authentication of the black (Mycteroperca bonaci), dusky (M. marginata) and goliath (E. itajara), and other groupers.

\section{SNPs}

A total of 94 SNPs were observed for correct identification both among and within genera, and among species (Fig. 6). Previously, a minimum of 60 SNPs was suggested as necessary for good forensic/ authentication diagnostics (Sobrino et al. 2005). The evidence provided herein (94 SNPs) indicate the robustness of the genetic features observed regarding a DNA authentication method. Traditional (as shown herein) and alternative barcoding regions have been used to examine the authentication and traceability of cattle meat (Fontanesi et al. 2010), wildlife (Sato et al. 2010, Ferreira et al. 2011) and fish (Baker and Palumbi 1994, Comi et al. 2005, Ogden 2008, Rasmussen and Morrissey 2008, Holmes et al. 2009, Ardura et al. 2010, Supernault et al. 2010, Carvalho et al. 2011a). Thus, correct species identification by SNP positions (Table 4) illustrates that the current barcode regions are very useful for fishery management. A clear example is the red grouper (Epinephelus morio), which has 29 autapomorphic SNPs (Table 4, Fig. 6) and which now has an important tool to prevent its exploitation (Morris et al. 2000, Sadovy 2001, Olavo et al. 2005, Freitas et al. 2011).

In addition, the barcode distinctiveness observed between the two Mycteroperca and Epinephelus spp. (Table 3) indicates the efficiency of the presented protocol. According to Ward et al. (2009) and Carvalho 
et al. (2011b), congeneric fish species are genetically (COI) different at a minimum rate of $8.4 \%$. Thus, the minimum COI difference of $10.3 \%$ (Mycteroperca marginata X M. bonaci, Table 3) seems to be high enough to state that the presented SNP-based protocol is an accurate DNA authentication procedure. In practical terms, sites 93 and 258 (Fig. 6, arrows) support this statement because they allow the simultaneous identification of those four overexploited and legally protected species as E. itajara by presenting a different nucleotide in each of the species.

In summary, we developed and tested the DNA barcoding as an effective tool for monitoring fisheries and illegal trade in groupers, including the endangered goliath grouper.

\section{ACKNOWLEDGEMENTS}

The authors are grateful to the Conservation Leadership Programme for supporting this project, to the Fundação de Amparo à Pesquisa do Estado da Bahia (FAPESB), to the Coordenação de Aperfeiçoamento de Pessoal de Nivel Superior (CAPES) and to Conservation International Brazil - Marine Programme for grants to M.O. Freitas. We thank Projeto Meros do Brasil (Programa Petrobrás Ambiental), Juliane Cebola (Universidade Estadual de Maringá), Dr. Ronaldo Francini-Filho (Universidade Federal da Paraíba), Dr. Rodrigo Leão de Moura (Universidade Federal do Rio de Janeiro) and Guilherme Dutra (Conservation International Brazil - Marine Programme) for their support. The authors are very grateful to the three anonymous referees for their contributions to the original submission. The first author is grateful to Petrobras, $\mathrm{CNPq}$ (Research Fellowship and Edital Universal 2007 both to R.A. Torres) and FACEPE for the grants supporting this study. R.A.T. is also grateful to Dr. Mauro Nirchio for translating the abstract to Spanish.

\section{REFERENCES}

Alacs E.A., Georges A., FitzSimmons N.N., Robertson J. 2012. DNA detective: a review of molecular approaches to wildlife forensics. Foren. Sci. Med. Pathol. doi 10.1007/s12024-009-9131-7.

Ardura A., Linde A.R., Moreira J.C., Garcia-Vazquez E. 2010 DNA barcoding for conservation and management of Amazonian commercial fish. Biol. Conserv. 143: 1438-1443.

Baker C.S., Palumbi S.R. 1994. Which whales are hunted? A molecular genetic approach to monitoring whaling. Science. 165: $1538-1539$.

Butler J.M. 2005. Forensic DNA Typing: Biology, Technology, and Genetics of STR Markers (2nd ed.). Burlington, Academic Press.

Calendini F., Martin J.-F. 2005. PaupUp v1.0.2032.22590 Beta. A free graphical frontend for Paup* Dos Software.

Carvalho D.C., Neto D.A., Brasil B.S., Oliveira D.A. 2011a. DNA barcoding unveils a high rate of mislabeling in a commercial freshwater catfish from Brazil. Mitochon. DNA. doi:10.3109/19 401736.2011.588219

Carvalho D.C., Oliveira D.A.A., Pompeu P.S., Leal C.G., Oliveira C., Hanner R. 2011b. Deep barcode divergence in Brazilian freshwater fishes: the case of the São Francisco River basin. Mitochon. DNA. 22 (S1): 80-86.

Claro R., Lindeman K.C., Parenti L.R. 2001. Ecology of the marine fishes of Cuba. Smithsonian Institution Press, Washington.

Comi G., Iacumin L., Rantsiou K., Cantoni C., Cocolin L. 2005. Molecular methods for the differentiation of species used in production of cod-fish can detect commercial frauds. Food Contr. 16: 37-42.

Craig M.T., Hastings P.A. 2007. A molecular phylogeny of the groupers of the subfamily Epinephelinae (Serranidae) with a revised classification of Epinephelini. Ichthyol. Res. 54: 1-17.

Dubey B., Meganathan P.R., Haque I. 2010. Molecular identification of three Indian snake species using simple PCR-RFLP Method. J. Forens. Sci. 55(4): 1065-1067.

Fernandez-Tajes J., Méndez J. 2007. Identification of the razor clam species Ensis arcuatus, E. siliqua, E. directus, E. macha, and Solen marginatus using PCR-RFLP analysis of the 5S rDNA region. J. Agricul. Food Chem. 55(18): 7278-7282.

Ferreira P.B., Torres R.A., Garcia J.E. 2011. Single nucleotide polymorphisms from cytochrome b gene as a useful protocol in forensic genetics against illegal hunting of manatees: Trichechus manatus, Trichechus inunguis, Trichechus senegalensis, and Dugong dugon (Eutheria: Sirenia). Zoologia 28(1): 133-138.

Fontanesi L., Scotti E., Russo V. 2010. Analysis of SNPs in the Kit gene of cattle with different coat colour patterns and perspective to use these markers for breed traceability and authentication of beef and dairy products. It. J. Anim. Sci. 9: 217-221.

Frédou T., Ferreira B.P. 2005. Bathymetric trends of Northeastern Brazilian snappers (Pisces, Lutjanidae): Implications for the reef fishery dynamic. Brazil. Arch. Biol. Technol. 48: 787-800.

Freitas M.O., Moura R.L., Francini-Filho R.B., Minte-Vera C.V. 2011. Spawning patterns of commercially important reef fishes (Lutjanidae and Serranidae) in the tropical Western South Atlantic. Sci. Mar. 75(1): 135-146.

Frézal L., Leblois R. 2008. Four years of DNA barcoding: Current advances and prospects. Infec. Genet. Evol. 8 (5): 727-736.

Frias-Torres S. 2007. Habitat use of juvenile goliath grouper Epinephelus itajara in the Florida Keys, USA. End. Species Res. 2: 1-6.

Gerhardinger L.C., Freitas M.O., Bertoncini A.A., Hostim-Silva M. 2006. Collaborative approach in the study of the reproductive biology of the dusky grouper Epinephelus marginatus (Lowe, 1834) (Perciformes: Serranidae). Act. Scient.: Biol. Sc. 28: 219-226.

Gerhardinger L.C., Hostim-Silva M., Medeiros R.P., Matarezi J., Bertoncini A.A., Freitas M.O., Ferreira B.P. 2009. Fishers' resource mapping and goliath grouper Epinephelus itajara (Serranidae) conservation in Brazil. Neotrop. Ichthyol. 7(1): 93-102.

Gimenez-Hurtado E., Coyula-Perez-Puelles R., Lluch-Cotac S.E., González-Yañeza A.A., Moreno-García V., Burgos-de-la-Rosa R. 2005. Historical biomass, fishing mortality, and recruitment trends of the Campeche Bank red grouper (Epinephelus morio). Fish. Res. 71: 267-277.

Hajibabaei M., Singer G., Hebert P., Hickey D. 2007. DNA barcoding: how it complements taxonomy, molecular phylogenetics and population genetics. Trend. Genet. 23(4): 167-72.

Hall T. 1999. Bioedit: a user-friendly biological sequence alignment editor and analysis program for Windows 95/98/NT. Nucl. Acid. Res. 41: 95-98.

Hall B.G. 2001. Phylogenetics trees made easy. A how to manual for molecular biologists. Sunderland, MA: Sinauer Associates, Inc.

Hauser L., Seeb J.E. 2008. Advances in molecular technology and their impact on fisheries genetics. Fish Fish. 9: 473-486.

Hebert P.D.N., Ratnasingham S., deWaard J.R. 2003. Barcoding animal life: cytochrome c oxidase subunit 1 divergences among closely related species. Proc. Royal Soc. Lond. B. 270: S96-S99.

Hebert P.D.N., Penton E.H., Burns J.M., Janzen D.H., Hallwachs W. 2004a. Ten species in one: DNA barcoding reveals cryptic species in the neotropical skipper butterfly Astraptes fulgerator. PNAS 101: 14812-14817.

Heemstra P.C., Randall J.E. 1993. FAO species catalogue. Vol. 16. Groupers of the world (Family Serranidae, Subfamily Epinephelinae). An annotated and illustrated catalogue of the grouper, rockcod, hind, coral grouper and lyretail species known to date. FAO Fish. Synop. 125(16): 1-382.

Holmes B.H., Steinke D., Ward R.D. 2009. Identification of shark and ray fins using DNA barcoding. Fish. Res. 95: 280-288.

Hostim-Silva M., Bertoncini A.A., Gerhardinger L.C., Machado L.F. 2005. The lord of the rocks conservation program in Brazil: the need for a new perception of marine fishes. Cor. Reef. 24: 74. 
Hsieh C.-H., Chang W.-T., Chang H.C., Hsieh H.-S., Chung Y.-L., Hwang D.-F. 2010. Puffer fish-based commercial fraud identification in a segment of cytochrome $b$ region by PCR-RFLP analysis. Food Chem. 121: 1305-1311.

IBAMA 2007. Portaria IBAMA N ${ }^{\circ} 42 / 2007$.

IUCN 2008. 2008 IUCN Red List of Threatened Species. <http:// www.iucnredlist.org/>. Acessed 10/31/2008.

Jacquet J., Pauly, D. 2008. Trade secrets: renaming and mislabeling of seafood. Mar. Pol. 32: 309-318.

Jobling M., Gill, P. 2004. Encoded evidence: DNA in forensic analysis. Nat. Rev. Genet. 5: 739-752.

Kang S., Sultana T., Loktev V., Wongratanacheewin S., Sohn W.M., Eom K., Park J.-K. 2008. Molecular identification and phylogenetic analysis of nuclear rDNA sequences among three opisthorchid liver fluke species (Opisthorchiidae: Trematoda). Parasitol. Internat. 57 (2): 191-197.

Linacre A., Tobe, S.S. 2011. An overview to the investigative approach to species testing in wildlife forensic science. Investigative Genet. 2: 2-9.

Machado L.F., Bertoncini A.A., Hostim-Silva M., Barreiros J.P. 2003. Habitat use by the juvenile dusky grouper Epinephelus marginatus and its relative abundance, in Santa Catarina, Brazil. Aqua: J. Ichthyol. Aquat. Biol. 6(4): 133-138.

McDonald W., Fry B., Deighton M. 2005. Identification of Streptococcus spp. causing bovine mastitis by PCR-RFLP of 16S-23S ribosomal DNA. Vet. Microbiol. 111(3-4): 241-246.

Meyer, R., Hoefelein, C., Luethy, J., Candrian, U. 1995. Polymerase chain reaction-restriction fragment length polymorphism analysis: a simple method for species identification in food. J. AOAC Internat. 78: 1542-1551.

Miller D.D., Mariani S. 2010. Smoke, mirrors, and mislabeled cod: poor transparency in the European seafood industry. Front. Ecol. Envir. 8(10): 517-521.

Mitcheson Y.S., Cornish A., Domeier M., Colin P.L., Russell M., Lindeman K.C. 2008. A global baseline for spawning aggregations of reef fishes. Conserv. Biol. 22(5): 1233-1244.

Mitcheson Y.S., Craig M.T., Bertoncini A.A., Carpenter K.E., Cheung W.W.L., Choat J.H., Cornish A.S., Fennessy S.T., Ferreira B.P., Heemstra P.C., Liu M., Myers R.F., Pollard D.A., Rhodes K.L., Rocha L.A., Russell B.C., Samoilys M.A., Sanciangco J. 2012. Fishing groupers towards extinction: a global assessment of threats and extinction risks in a billion dollar fishery. Fish Fish. DOI: 10.1111/j.1467-2979.2011.00455.x.

Morin P.A., Luikart G., Wayne R.K., the SNP workshop group. 2004. SNPs in ecology, evolution and conservation. Trend. Ecol. Evol. 19(4): 208-216.

Morris A.V., Roberts C.M., Hawkins J.P. 2000. The threatened status of groupers (Epinephelinae). Biodiv. Conserv. 9: 919-942.

Nelson J.S. 2006. Fishes of the world. John Wiley and Sons, Inc. New York. 4th edition.

Ogden R. 2008. Fisheries forensics: the use of DNA tools for improving compliance, traceability and enforcement in the fishing industry. Fish Fish. 9: 462-472.

Olavo G., Costa P.A., Martins A.S. 2005. Caracterização da pesca de linha e dinâmica das frotas linheiras da Bahia. In: Costa P.A.S., Martins A.S., Olavo G. (eds.) Pesca e potenciais de exploração de recursos vivos na região central da Zona Econômica Exclusiva brasileira. Rio de Janeiro: Museu Nacional.

Palo J.U., Merila J. 2003. A simple RFLP method for identification of two ranid frogs. Conserv. Genet. 4: 801-803.

Partis L., Croan D., Guo Z., Clark R., Coldham T., Murby J. 2000. Evaluation of a DNA fingerprinting method for determining the species origin of meats. Meat Sci. 54: 369-376.

Pauly D. 2009. Beyond duplicity and ignorance in global fisheries. Sci. Mar. 73(2): 215-224.

Pauly D., Watson R., Alder J. 2005. Global trends in world fisheries: Impacts on Marine ecosystems and food security. Phil. Trans. Royal Soc. B 360: 5-12.

Pauly D., Christensen V., Guenette S., Pitcher T. 2002. Towards sustainability in world fisheries. Nature 418: 689-695.

Rasmussen R.S., Morrissey M.T. 2008. DNA-based methods for the identification of commercial fish and seafood species. Compreh. Rev. Food Sc. Food Saf. 7: 280-295.
Rohilla M.S., Tiwari P.K. 2008. Restriction fragment length polymorphism of mitochondrial DNA and phylogenetic relationships among five species of Indian fresh water turtles. J. Appl. Genet. 49:167-82

Sadovy Y., Eklund A. 1999. Synopsis of biological data on the Nassau grouper, Epinephelus striatus (Bloch, 1792), and the Jewfish, E. itajara (Lichtenstein, 1822). NOAA Tech. Rep. NMFS: 146.

Sadovy Y. 2001. The threat of fishing to highly fecund fishes. $J$. Fish Biol. 59: 90-108.

Santaclara F., Espiñeira M., Cabado A., Vieites J. 2007. Detection of land animal remains in fish meals by the polymerase chain reaction-restriction fragment length polymorphism technique. J. Agr. Food Chem. 55 (2): 305-310.

Sass C., Little D., Stevenson D., Specht C., Dilkes B. 2007. DNA Barcoding in the Cycadales: Testing the potential of proposed barcoding markers for species identification of Cycads. PLoS ONE 2(11): 1-9.

Sato I., Nakaki S., Murata K., Takeshita H., Mukai T. 2010. Forensic hair analysis to identify animal species on a case of pet animal abuse. Intern. J. Leg. Med. 124: 249-256.

Schlötterer C. 2004. The evolution of molecular markers just a matter of fashion? Nat. Rev. Genet. 5 (1): 63-9.

Sobrino B., Brión M., Carracedo A. 2005. SNPs in forensic genetics: a review on SNP typing methodologies. Foren. Sc. Internat. 154: 181-194.

Song H., Buhay J., Whiting M., Crandall K. 2008. Many species in one: DNA barcoding overestimates the number of species when nuclear mitochondrial pseudogenes are coamplified. PNAS 105 (36): 13486-13491.

Sowmya P., Dhanya V., Madhavan H., Therese K. 2007. Comparative efficacy of PCR-based restriction fragment length polymorphism (RFLP) and multiplex PCR for glycoprotein B (gB) genotyping of human cytomegalovirus. Ind. J. Med. Res. 126: 122-127.

Spergser J., Rosengarten R. 2007. Identification and differentiation of canine Mycoplasma isolates by $16 \mathrm{~S}-23 \mathrm{~S}$ rDNA PCR-RFLP. Veter. Microbiol. 125 (1-2): 170-174.

Supernault K.J., Demsky A., Campbell A., Ming T.J., Miller K.M., Withler R.E. 2010. Forensic genetic identification of abalone (Haliotis spp.) of the northeastern Pacific Ocean. Conserv. Genet. 11: 855-865.

Teixeira S.F., Ferreira B.P., Padovan I.P. 2004. Aspects of fishing and reproduction of the black grouper Mycteroperca bonaci (Poey 1860) (Serranidae: Epinephelinae) in the Northeastern Brazil. Neotrop. Ichthyol. 2(1): 19-30.

Torres R.A. 2006. Molecular taxonomy of Plagioscion Heckel (Perciformes, Sciaenidae) and evidence from mtDNA RFLP markers for an invasive species in the Paraná River, Southern Brazil. Rev. Bras. Zool. 23(4): 1235-1242.

Verkaar E., Nijman I., Boutaga K., Lenstra J. 2002. Differentiation of cattle species in beef by PCR-RFLP of mitochondrial and satellite DNA. Meat Sc. 60: 365-369.

Ward R.D., Zemlak T., Innes B., Last P., Hebert P. 2005. DNA barcoding Australia's fish species. Phil. Trans. Royal Soc. B. 360(1462): 1847-1857.

Ward R.D., Hanner R., Hebert P.D.N. 2009. The campaign to DNA barcode all fishes, FISH-BOL. J. Fish Biol. 74: 329-356.

Ward R.D., Costa F.O., Holmes B.H., Steinke D. 2008. DNA barcoding of shared fish species from the North Atlantic and Australasia: minimal divergence for most taxa, but Zeus faber and Lepidopus caudatus each probably constitute two species. Aquat. Biol. 3: 71-78.

Wolf C., Rentsch J., Huebner P. 1999. PCR-RFLP analysis of mitochondrial DNA: a reliable method for species identification. $J$. Agr. Food Chem. 47: 1350-1355.

Wong E., Hanner R. 2008. DNA barcoding detects market substitution in North American seafood. Food Res. Internat. 41(8): 828-837.

Scient. ed.: J. Viñas.

Received January 7, 2013. Accepted May 31, 2013.

Published online July 29, 2013. 